\title{
Structure and composition of the ground-herb community in a terra-firme Central Amazonian forest.
}

\author{
Flávia Regina Capellotto COSTA ${ }^{1}$
}

\begin{abstract}
The herb community of tropical forests is very little known, with few studies addressing its structure quantitatively. Even with this scarce body of information, it is clear that the ground herbs are a rich group, comprising 14 to $40 \%$ of the species found in total species counts in tropical forests. The present study had the objective of increasing the knowledge about the structure and composition of the ground-herb community and to compare the sites for which there are similar studies. The study was conducted in a tropical non-inundated and evergreen forest $90 \mathrm{~km}$ north of Manaus, AM. Ground herbs were surveyed in 22 transects of $40 \mathrm{~m}^{2}$, distributed in five plots of 4 ha. The inventoried community was composed of 35 species, distributed in 24 genera and 18 families. Angiosperms were represented by 8 families and Pteridophytes by 10 families. Marantaceae (12 sp) and Cyperaceae ( $4 \mathrm{sp}$ ) were the richest families. Marantaceae and Poaceae were the families with greatest abundance and cover. Marantaceae, Poaceae, Heliconiaceae and Pteridophytes summed 96\% of total herb cover, and therefore were responsible for almost all the cover of the community. The 10 most important species had $83.7 \%$ of the individuals. In general, the most abundant species were also the most frequent. Richness per transect varied from 7 to 19 species, and abundance varied from 30 to 114 individuals. The community structure was quite similar to 3 other sites in South America and one site in Asia.
\end{abstract}

\section{KEY WORDS}

Amazonia; community structure; herbs; tropical forest; understory.

\section{Estrutura e composição da comunidade berbácea terrestre em uma floresta de terra-firme da Amazônia Central.}

\begin{abstract}
RESUMO
A comunidade berbácea das florestas tropicais é pouco conbecida, bavendo poucos estudos quantitativos de sua estrutura. Mesmo com esta quantidade escassa de informações, é possível afirmar que as ervas terrestres são um grupo rico, representando 14 a 40\% das espécies encontradas em contagens totais de espécies em florestas tropicais. O presente estudo teve como objetivo aumentar o conbecimento sobre a estrutura e composição da comunidade de ervas terrestres e comparar as localidades para as quais há estudos similares. O estudo foi desenvolvido em uma floresta tropical nãoinundada, $90 \mathrm{~km}$ ao norte de Manaus, AM. As ervas terrestres foram amostradas em 22 transectos de $40 \mathrm{~m}^{2}$, distribuídos em cinco plots de $4 \mathrm{ha}$. A comunidade foi composta de 35 espécies, distribuídas em 24 gêneros e 18 famílias. As angiospermas foram representadas por 8 famílias e as pteridófitas por 10 famílias. Marantaceae (12 sp) e Cyperaceae (4 sp) foram as famílias mais ricas em espécies. Marantaceae e Poaceae foram as famílias com maior abundância e cobertura. A cobertura de Marantaceae, Poaceae, Heliconiaceae e pteridófitas somou 96\% de toda a cobertura berbácea, e assim estes 4 grupos foram responsáveis por quase toda a cobertura da comunidade. As 10 espécies mais abundantes somaram $83,7 \%$ dos indivíduos. Em geral as espécies mais abundantes foram também as mais freqüentes. A riqueza por transecto variou de 7 a 19 espécies, e a abundância variou de 30 a 114 indivíduos. A estrutura da comunidade foi bastante similar à encontrada em 3 outras localidades na América do Sul e uma na Ásia.
\end{abstract}

PALAVRAS-CHAVE

Amazonia; estrutura de comunidades; ervas; floresta tropical; sub-bosque.

${ }^{1}$ Coordenação de Pesquisas em Ecologia, Instituto Nacional de Pesquisas da Amazônia, CP 478 CEP 69011-970, Manaus - AM, Fone/fax: 055-92-6421838, e-mail: anfe@inpa.gov.br 


\section{ACTA \\ AMAZONICA}

STRUCTURE AND COMPOSITION OF THE GROUND-HERB

COMMUNITY IN A TERRA-FIRME CENTRAL AMAZONIAN FOREST

\section{INTRODUCTION}

The amount of inventories of the tree strata of tropical forests has grown in the last decades, and it is already possible to know what can be expected from the structure and composition of this strata for some regions and to establish the compositional relationships among areas (Gentry, 1988; Duivenvoorden \& Lips, 1995; Terborgh \& Andresen, 1998; Ter Steege, 2000; de Oliveira \& Nelson, 2001 and references on plot inventories on these papers). Besides this increase in the knowledge of the canopy, the understory of tropical forests remained largely unknown. Few studies addressed its composition and structure (Gentry \& Dodson, 1987; Gentry \& Emmons, 1987) or included it in total species counts in plots of known size (Hall \& Swaine, 1976; Whitmore et al., 1985; Gentry \& Dodson, 1987; Duivenvoorden \& Lips, 1995; Ter Steege, 2000). The herb component of the understory was examined quantitatively by just two studies all around the tropical region (Poulsen \& Balslev, 1991; Poulsen, 1996), two other studies include herb species lists for plots of known size, although they do not present estimates of abundance for each species (Turner, 1996; Duivenvoorden \& Lips, 1995), and another two studies sampled the composition and structure of the herb community in gaps (Smith, 1987; Dirzo et al., 1992). There is a growing number of studies of the forest herb strata in Brazil, but these are confined to the subtropical region of the south (Citadini-Zanete 1984; Cestaro et al., 1986; Diesel, 1991; Dorneles \& Negrele, 1999; Müller \& Waechter, 2001).

The understory of tropical forests is species-rich, containing 21 to $47 \%$ of total species present in Neotropical forests (Croat, 1978; Dodson \& Gentry, 1978; Gentry \& Dodson, 1987; Dodson et al., 1985). Herbs may represent 8 to $29 \%$ (mean of $17 \%$ for 5 sites) of the species found in total species counts in moist to wet forests, $53 \%$ in dry forest and 0 to $6 \%$ in forests with white sand soil (Hall \& Swaine, 1976; Gentry \& Dodson, 1987; Gentry \& Emmons, 1987; Whitmore et al., 1985).

Given the lack of information about the understory of tropical forests, this study aimed to increase the knowledge about the structure and composition of the tropical understory herb community and to compare the sites for which there are similar studies.

\section{MATERIAL AND METHODS}

\section{Study site}

This study was conducted at the Experimental Forest Management Station ZF-2 of the National Institute for Amazonian Research (INPA), located at 2。 37' S, 60 11' W, 90 $\mathrm{km}$ north of Manaus, Brazil. The site is covered by terra-firme evergreen forest on a gently rolling topography which alternates well-drained flat plateaus and wet to inundated bottomlands. The present study was conducted on a generally flat plateau. Soils are acidic and nutrient poor yellow latosols
(Brasil, 1978; Ranzani, 1980). The climate is warm and humid, with mean annual precipitation of ca. $2478 \mathrm{~mm}$ (Ribeiro, 1976), concentrated between December and May. Mean annual temperature is $27.6 \mathrm{C}$ (IPEAAOC, 1971).

\section{Community data collection}

The herb community in this study includes only the real herbs, plants without woody tissue, and therefore seedlings of trees and shrubs are not considered. Only those herbaceous species that spend their entire life cycle on the forest floor were considered as members of the ground-herb community. This definition excludes climbers and fallen epiphytes. The sampled community includes most of the "obligate terrestrial" herb group in the definition of Poulsen \& Balslev (1991). Saprophytes were not included, because they are seasonal in aboveground presence and could not be effectively sampled using the same technique as the other species.

Data were collected from October 1996 to February 1997. The species composition was surveyed in 22 transects of $80 \times 0.5 \mathrm{~m}$, distributed in groups of 4 transects per plot, with the exception of one group of six transects in a plot. Plots had 4 ha and were 50 to $1300 \mathrm{~m}$ apart; transects inside plots were $25 \mathrm{~m}$ apart. All plots were installed in the upper and flat portions of the topography, locally called "platôs", as part of an experiment by INPA's Department of Tropical Silviculture (Higuchi et al., 1985). Therefore, slopes and valley bottoms were not included in the sampling.

All ground herbs in each transect, from seedlings greater than $5 \mathrm{~cm}$ in height to adults, were counted and identified. For the majority of the species, it was possible to distinguish and count individuals. In clonal species, each clump was counted as an individual. Plants were identified by comparison with a field guide prepared from vouchers collected in the same area and identified at the INPA Herbarium, with the help of INPA's Botany Department staff and researchers of the Ducke Reserve Flora Project. Identifications were cross-checked against the guide "Flora da Reserva Ducke" (Ribeiro et al., 1999). Vouchers of fertile material were deposited at the INPA Herbarium.

Cover was calculated for each individual as the area of an ellipse determined by the major and minor diameters of its crown. As this measure is not accurate, the absolute values of cover are not provided here and only relative cover was used to compare the species contribution to the community structure.

\section{RESULTS}

The sampled ground-herb community of the terra-firme plateau was composed by a total of 35 species, distributed in 24 genera and 18 families. Angiosperms were represented by 8 families, of which Marantaceae (12 sp) and Cyperaceae (4 sp) were the richest (Table 1). Pteridophytes comprised 10 families, of which only Selaginellaceae had more than 1 species. 


\section{ACTA AMAZONICA}

Table 1 - List of the ground-herb species sampled on the plateaus of the ZF-2 Management Station, Manaus, AM.

\begin{tabular}{|c|c|}
\hline Family & Species \\
\hline \multicolumn{2}{|l|}{ PTERIDOPHYTES } \\
\hline Dennstaedtiaceae & Lindsaea lancea (L.) Bedd. \\
\hline Dryopteridaceae & Polybotrya sp. \\
\hline Hymenophyllaceae & Trichomanes pinnatum Hedw. \\
\hline Lomariopsidaceae & Lomariopsis prieuriana Fée \\
\hline Marattiaceae & Danaea trifoliata Kunze \\
\hline Metaxyaceae & Metaxya rostrata (Willd.) Presl. \\
\hline Pteridaceae & Adiantum cajennense Willd. ex Klotzsch \\
\hline Schizaeaceae & Schizaea elegans (Vahl) Sw. \\
\hline Selaginellaceae & $\begin{array}{l}\text { Selaginella breynii Spring } \\
\text { Selaginella sp. }\end{array}$ \\
\hline Tectariaceae & Triplophyllum dicksonioides (Fée) Holttum \\
\hline \multicolumn{2}{|l|}{ ANGIOSPERMS } \\
\hline Araceae & $\begin{array}{l}\text { Dieffenbachia elegans Jonker-Verhoef \& Jonker } \\
\text { Dracontium longipes Engl. }\end{array}$ \\
\hline Bromeliaceae & Bromelia tubulosa L.B. Smith \\
\hline Cyperaceae & $\begin{array}{l}\text { Calyptrocarya bicolor (H. Pfeiff.) T. Koyama } \\
\text { Calyptrocarya glomerulata (Brongn.) Urb. } \\
\text { Diplasia karataefolia Rich. } \\
\text { Mapania sylvatica Aubl. }\end{array}$ \\
\hline Heliconiaceae & Heliconia acuminata Rich. ssp. occidentalis L. Andersson \\
\hline Marantaceae & $\begin{array}{l}\text { Calathea altissima (Poepp. \& Endl.) Koern. } \\
\text { Calathea cannoides (Nicholson) Kennedy } \\
\text { Calathea mansonis Koern. } \\
\text { Calathea sp. } \\
\text { Ischnosiphon arouma (Aubl.) Koern. } \\
\text { Ischnosiphon killipii Macbr. } \\
\text { Ischnosiphon gracilis (Rudge) Koern. } \\
\text { Ischnosiphon martianus Eichl. ex Peters. } \\
\text { Ischnosiphon puberulus Loes. } \\
\text { Ischnosiphon surinamensis (Miq.) Koern. } \\
\text { Monotagma spicatum Aubl. Macbr. } \\
\text { Monotagma sp. }\end{array}$ \\
\hline Piperaceae & Piper consanguineum Kunth. \\
\hline Poaceae & $\begin{array}{l}\text { Ichnanthus panicoides Beauv. } \\
\text { Pariana radiciflora Doell }\end{array}$ \\
\hline Zingiberaceae & Renealmia floribunda K. Schum. \\
\hline
\end{tabular}

Pteridophytes (all families together) were the most abundant group with $54 \%$ of the individuals. Marantaceae and Poaceae were the following most abundant families, comprising 24 and $11 \%$ of all individuals, respectively. In terms of cover, pteridophytes drop to the fourth position, but is still one of the most important groups. The cover of Marantaceae (55.6\%), Poaceae (16.5\%), Heliconiaceae (12.7\%) and Pteridophytes (11\%) summed to $96 \%$ of the total herb cover, and therefore these four groups are responsible for almost all cover of the community.

The community was dominated, in numbers, by the small fern Trichomanes pinnatum, which alone accounted for $38.8 \%$ of all individuals. The three most abundant species in the community, T. pinnatum, Monotagma spicatum and Pariana radiciflora represented $60.8 \%$ of the individuals, and the 10 most abundant species had 83.7 $\%$ of the individuals (Table 2). Only two species were represented by single individuals.

Trichomanes pinnatum was also the most frequent species in the transects (100\% frequency), followed by Heliconia acuminata (95\%) and Lindsaea lancea (90\%). In general, the most abundant species were also the most frequent (Table 2). Six species were present in only one transect.

The species' rank in relative cover was also related to the rank of density. The three species with the greatest relative cover Monotagma spicatum (31.5\%), Pariana radiciflora (16.2\%) and Heliconia acuminata (12.7\%) were among the most abundant species. However, the abundant ferns $T$. pinnatum and L. lancea were only the sixth and the thirteenth species in the rank of cover, due to their small size.

Richness per transect $\left(40 \mathrm{~m}^{2}\right)$ varied from 7 to 19 species, with a mean of 11.5 species. The species- 
Table 2 - Summary of the structure of the herb community on the plateaus of the ZF-2 Management Station, Manaus, AM. Species are ranked by total density.

\begin{tabular}{|c|c|c|c|}
\hline Species & $\begin{array}{c}\text { Total } \\
\text { Density }\end{array}$ & $\begin{array}{c}\text { Relative } \\
\text { Cover (\%) }\end{array}$ & Frequency \\
\hline Trichomanes pinnatum & 499 & 6.82 & 100.0 \\
\hline Monotagma spicatum & 148 & 31.55 & 86.4 \\
\hline Pariana radiciflora & 134 & 16.21 & 77.3 \\
\hline Lindsaea lancea & 80 & 0.99 & 90.9 \\
\hline Heliconia acuminata & 79 & 12.70 & 95.5 \\
\hline Lomariopsis prieuriana & 52 & 3.83 & 81.8 \\
\hline Calathea mansonis & 30 & 1.14 & 27.3 \\
\hline Monotagma sp. & 27 & 2.88 & 13.6 \\
\hline Calathea altissima & 27 & 1.77 & 54.5 \\
\hline Ischnosiphon arouma & 27 & 6.82 & 68.2 \\
\hline Mapania sylvatica & 24 & 1.12 & 45.5 \\
\hline Triplophyllum dicksonioides & 18 & 0.73 & 40.9 \\
\hline Adiantum cajennense & 17 & 0.41 & 45.5 \\
\hline Ischnosiphon martianus & 16 & 2.75 & 50.0 \\
\hline Calyptrocarya bicolor & 12 & 0.89 & 18.2 \\
\hline Calathea cannoides & 12 & 0.67 & 27.3 \\
\hline Selaginella sp. & 10 & 0.12 & 18.2 \\
\hline Dieffenbachia elegans & 10 & 0.20 & 22.7 \\
\hline Ischnosiphon surinamensis & 10 & 6.92 & 36.4 \\
\hline Ichnanthus panicoides & 9 & 0.24 & 27.3 \\
\hline Polybotrya sp. & 9 & 0.25 & 13.6 \\
\hline Dracontium longipes & 5 & 0.11 & 18.2 \\
\hline Calyptrocarya glomerulata & 4 & 0.19 & 4.5 \\
\hline Ischnosiphon puberulus & 3 & 0.36 & 13.6 \\
\hline Calathea sp. & 3 & 0.16 & 4.5 \\
\hline Bromelia tubulosa & 3 & 0.96 & 13.6 \\
\hline Selaginella breynii & 3 & 0.08 & 9.1 \\
\hline Ischnosiphon gracilis & 2 & 0.06 & 9.1 \\
\hline Metaxya rostrata & 2 & 0.07 & 4.5 \\
\hline Ischnosiphon killipii & 2 & 0.47 & 9.2 \\
\hline Renealmia floribunda & 2 & 0.18 & 9.2 \\
\hline Piper consanguineum & 2 & 0.09 & 4.5 \\
\hline Danaea trifoliata & 2 & 0.02 & 4.5 \\
\hline Diplasia karataefolia & 1 & 0.46 & 4.5 \\
\hline Schizea elegans & 1 & 0.03 & 4.5 \\
\hline
\end{tabular}

area curve stabilized with 15 transects, which corresponds to $600 \mathrm{~m}^{2}$ (Figure 1a), indicating that the number of sampled transects (22) was enough to represent the herb composition of the plateau forest. The curve of species by individuals stabilizes around 1000 individuals (Figure 1b).

Total abundance in the 22 transects $\left(880 \mathrm{~m}^{2}\right)$ was 1285 individuals, which gives a density of 1.5 individuals $/ \mathrm{m}^{2}$. Mean abundance per transect $\left(40 \mathrm{~m}^{2}\right)$ was 58.6 individuals, varying from 30 to 114 .

\section{DISCUSSION}

At a first view, the number of groundherbs found at the terra-firme plateau of Manaus ( $35 \mathrm{sp}$ ) seems to be low, compared to other sites (Table 3). However, in most of these sites several habitats or environments were sampled and the size of the samples varied from 0.01 to $9 \mathrm{ha}$, which makes the comparisons difficult. Variation in topography is a large source of variation in composition of herbs, as was demonstrated by Tuomisto \& Ruokolainen (1994), Poulsen \& Balslev (1991) and Poulsen (1996). The only site for which detailed information on the topography was provided was the 1 ha plot in Borneo. At this plot, a sub-sample of 0.08 ha had topography comparable to the present study and yielded $31 \mathrm{sp}$, a number close to what was found in the 0.09 ha of the present study. The mean richness for sub-samples of 0.1 ha at Cuyabeno, Ecuador was $38 \mathrm{sp}$, which is also comparable to Manaus. However, the richness of two plots of 0.1 ha at Caquetá, Colombia (21 and 25 sp in each plot), with a soil type probably richer than that found in the Manaus plateaus, was well below the number found in Manaus. At several locations in Guyana the number of herb species in plots ranging from 0.04 to 0.25 ha varied from 5 to 21 in soils varying from white sands (very poor) to more clayey and probably moderately rich soils. One 0.1 ha sample from a rich soil site, Rio Palenque, Ecuador, had 50 herb species. The 0.1 ha sample at Capeira, which is a dry forest, also had a high number of species, but Gentry \& Dodson (1987) argue that most of them are weedy.

The amount of data available to date is still not enough to make generalizations, but it seems that the local richness of herbs in similar habitats, is more or less constant 


\section{ACTA \\ AMAZONICA}

geographically. Several authors have shown some relationship between understory diversity and soil fertility or topography (Gentry \& Emmons, 1987; Poulsen, 1996; Duivenvoorden \& Lips, 1995). Therefore, it is expected that samples with similar soil and topography will have the same number of herb species, irrespective of the geographical location. Gentry \& Dodson (1987) have examined the relationship between the richness of several plant habits with precipitation and soil fertility for 13 sites distributed in South and Central America. Even without a formal test, they have shown that high herb richness was correlated with fertile soils and high precipitation. However, most of the sites were concentrated in western South America, which makes geographical extrapolations doubtful. It will be necessary to sample new areas, covering central and eastern Amazonia and using a common sampling protocol to formally test this hypothesis.

Density of ground herbs at Manaus (1.5 individuals $/ \mathrm{m}^{2}$ ) was comparable to that found at Cuyabeno $\left(1.1 \mathrm{ind} / \mathrm{m}^{2}\right)$ and Rio Palenque $\left(1.2 \mathrm{ind} / \mathrm{m}^{2}\right)$. These sites are intermediate between the low density found at Brunei $\left(0.6 \mathrm{ind} / \mathrm{m}^{2}\right)$ and Jauneche $\left(0.9 \mathrm{ind} / \mathrm{m}^{2}\right)$ and the high density at Capeira $(2.8$

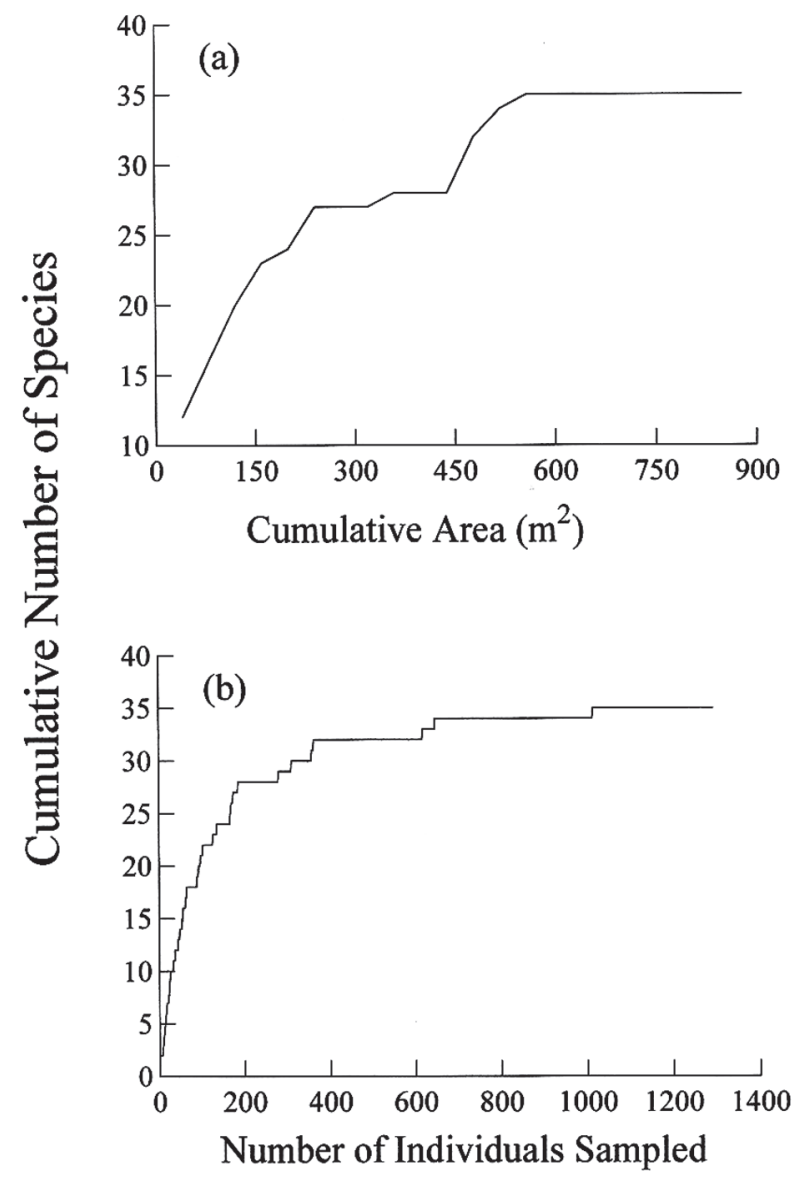

Figure 1 - Species-area (a) and species-individuals (b) curves for the samples of ground-herbs at the ZF-2 Management Station, Manaus, Brazil. ind $\left./ \mathrm{m}^{2}\right)$ and Los Tuxtlas $\left(13.3 \mathrm{ind} / \mathrm{m}^{2}\right)$. Capeira is a dry and disturbed forest, which is, according to Gentry \& Dodson (1987), the cause of its high herb density. At Los Tuxtlas the herb community was sampled in gaps, which may have increased the density estimate. Comparisons of density estimates are difficult because definitions of an "individual" are not standardized and are especially sensitive to the number of clonal species.

The number of Angiosperm families found in Manaus (8) was the lowest compared to all other sites, except the two plots in Acri-Ferralsol soil in Colombia, where only 4 to 5 families were present in 0.1 ha. Even the comparable 0.08 ha sub-sample of Borneo had 2 families more than Manaus, and two samples of 0.1 ha in Ali-Acrisol soil in Colombia had 3 to 5 families more than Manaus. The number of families was not very variable among sites, ranging from 8 to 14 .

The rank of family representation at Manaus was quite similar to Cuyabeno (Ecuador), and to a lesser degree to Caquetá (Colombia). Marantaceae was the most important family in species numbers both in Manaus (12 sp) and Cuyabeno ( $9 \mathrm{sp}$ ). Poaceae was the second richest family in Cuyabeno (8 sp) and the third in Manaus (2 sp), while Cyperaceae was the second in Manaus ( $4 \mathrm{sp}$ ) and the third in Cuyabeno ( $4 \mathrm{sp}$ ). Marantaceae was also the richest family in the upland plots in the middle Caquetá region of Colombia, with 3 to 5 species per 0.1 ha plot, and a total of 11 species in the summed sample of 0.4 ha. Cyperaceae was the second richest family at Caquetá, with 0-2 species in 0.1 plots and a total of 3 species in 0.4 ha sample. Poaceae was not an important family in Caquetá, with only 1 species in the total sample of 0.4 ha. In Manaus, the regional pool of Poaceae species is low, since the complete flora of the Ducke Reserve ( $50 \mathrm{~km}$ far from the present study site) registered only 4 forest grasses, and one of these is restricted to the forest margins. Restriction of the samples to the upland well-drained areas may be another possible cause of the low number of Poaceae species at Manaus and Caquetá.

The rank of family cover was also highly similar, with Marantaceae (56\% in Manaus, $18 \%$ in Cuyabeno), Poaceae (16\%, $25 \%)$, Heliconiaceae (13\%, $17 \%)$ and Pteridophytes (11\%, $23 \%)$ being the groups with the greatest cover. In Manaus these four groups summed $96 \%$ of relative cover and Marantaceae accounted for half of the total cover, while in Cuyabeno they summed $73 \%$, indicating that dominance was higher in Manaus.

There were also a high similarity in the species rank of cover in Manaus and Cuyabeno. The 3 species with greatest cover at the two sites were one Poaceae (Pariana radiciflora, at the two sites), one Heliconiaceae (Heliconia acuminata in Manaus, Heliconia velutina in Cuyabeno) and one Marantaceae (Monotagma spicatum in Manaus, Ischnosiphon puberulus in Cuyabeno), although the order was not the same.

The study at Borneo does not present cover values for species. The density rank of species in Borneo has a Zingiberaceae as the most abundant species, while in 


\section{ACTA \\ AMAZONICA}

STRUCTURE AND COMPOSITION OF THE GROUND-HERB

COMMUNITY IN A TERRA-FIRME CENTRAL AMAZONIAN FOREST

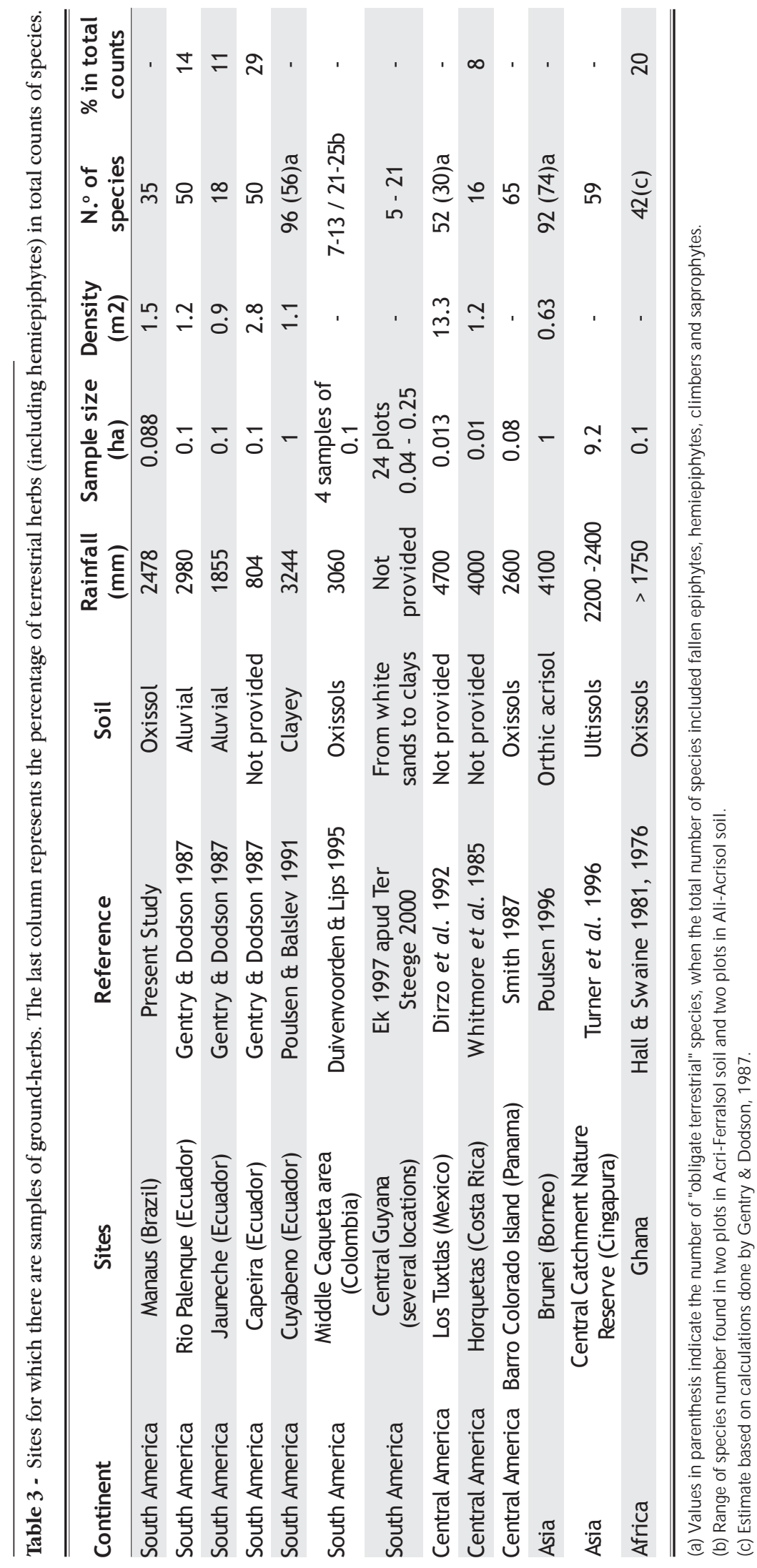

Manaus the first in the rank is a Marantaceae species. However, the second most abundant species in Borneo is one Trichomanes, the same fern genus to which pertains the most abundant species in Manaus. Another fern and one Cyperaceae are the third and fourth in the abundance rank, while in Manaus the third was a grass and the fourth a fern. Due to the biogeographical history, Marantaceae is not an important family in Borneo, and Zingiberaceae is not an important family at Manaus - in fact there is only one ginger species reported for the Manaus region. However, these families are very similar in morphology and could play similar ecological roles, being "ecological equivalents". Cyperaceae and Poaceae can also be considered equivalents. Therefore, the structure of the herb community of these very distant forests can be considered ecologically similar.

A common feature in the structure at family level in 5 sites (Manaus, Cuyabeno, Caquetá, Brunei and Singapore) was that only two families accounted for around half ( 40 to $67 \%$ ) of the number of species in the community. There is some reason to believe that this dominance increases as the soil fertility decreases, as the samples at Manaus and one of the soil types at Caquetá (the Acri-Ferralsol group), which are probably the poorest soils in this sample, had the greatest values of dominance $(0.67$ and 0.6 , respectively).

In conclusion, there is a high degree of similarity in the structure of the sites compared, despite their geographic distance. Patterns of variation in richness and composition are probably related to gradients in soil fertility and precipitation, as some studies are showing for selected understory groups (Gentry \& Emmons 1987, Tuomisto \& Ruokolainen 1994, Tuomisto \& Poulsen 1996), but much more data are necessary to reach a definitive conclusion.

\section{ACKNOWLEDGEMENTS}

I thank the Departments of Silviculture and Ecology of the Instituto Nacional de Pesquisas da Amazônia for providing field support and assistants. I am especially indebted to Maria de Lourdes Soares, from INPA's Botany 


\section{ACTA \\ AMAZONICA}

Department and to Dr. Mike Hopkins and the team of the Ducke Reserve's Flora Project, Anália Souza, Maria Auxiliadora da Costa, José Eduardo Ribeiro, Cynthia Sothers e Alberto Vicentini for the training in field recognition of species and the assistance in species identification at the herbarium. The author received a fellowship from the Brazilian National Research Council (CNPq) during the study.

\section{LITERATURE CITED}

Brasil 1978. Departamento Nacional da Produção Mineral. Projeto RADAM-BRASIL. Folha SA-20 Manaus: geologia, geomorfologia, vegetação e uso da terra. Rio de Janeiro, Brasil.

Cestaro, L.A.; Waechter, J.L.; Baptista, L.R.M. 1986. Fitossociologia do estrato herbáceo da mata de araucária da Estação Ecológica de Aracuri, Esmeralda, RS. Hoebnea, 13: 59-72.

Citadini-Zanette, V. 1984. Composição florística e fitossociologia da vegetação herbácea terrícola de uma mata de Torres, Rio Grande do Sul, Brasil. Iheringia, 32: 23-62.

Croat, T. 1978. Flora of Barro Colorado Island. Standford University Press, Stanford, California.

Diesel, S. 1991. Estudo fitossociológico herbáceo/arbustivo da mata ripária da bacia hidrográfica do rio dos Sinos, RS. Pesquisas, série Botânica, 42: 201-257.

Dirzo, R.; Horvitz, C.C.; Quevedo, H.; López, M.A. 1992. The effects of gap size and age on the understory herb community of a tropical Mexican rain forest. J. Ecol., 80: 809-822.

Dodson, C.; Gentry, A. 1978. Flora of the Rio Palenque Science Center. Selbyana, 4: 1-623.

Dodson, C.; Gentry, A.H.; Valverde, F.M. 1985. Flora ofJauneche, Los Rios, Ecuador. Banco Nacional de Ecuador, Quito.

Dorneles, L.P.P.; Negrele, R.R.B. 1999. Composição florística e estrutura do compartimento herbáceo de um estágio sucessional avançado da Floresta Atlântica, no sul do Brasil. Biotemas, 12: 7-30.

Duivenvoorden, J.F.; Lips, J.M. 1995. A land-ecological study of soils, vegetation, and plant diversity in Colombian Amazonia. Tropenbos Series 12, Tropenbos. Wageningen, The Netherlands.

Gentry, A.H. 1988. Changes in plant community diversity and floristic composition on environmental and geographical gradients. Ann. Mo. Bot. Gard., 75:1-34.

Gentry, A. H.; Dodson, H.C. 1987. Contribution of non-trees to species richness of tropical rain forest. Biotropica, 19: 149-156.

Gentry, A.H.; Emmons, L.H. 1987. Geographical variation in fertility, phenology and composition of the understory of neotropical forests. Biotropica, 19: 216-227.

Hall, J.B.; Swaine, M.D. 1976. Classification and ecology of closedcanopy forest in Ghana. J. Ecol., 64: 913-951.

Higuchi, N.; Jardim, F. C. S.; Santos, J.; Barbosa, A.P.; Wood, T. W. W. 1985. Bacia 3 - Inventário Florestal Comercial. Acta Amazonica, 15: 327-369.
Instituto de Pesquisas e Experimentação Agropecuárias da Amazônia Ocidental - IPEAAOC. 1971. Solos do Distrito Agropecuário da SUFRAMA. Manaus.

Müller, S.C.; Waechter, J.L. 2001. Estrutura sinusial dos componentes herbáceo e arbustivo de uma floresta costeira subtropical. Revta Brasil. Bot., 24: 395-406.

Oliveira, A.A.; Nelson, B.W. 2001. Floristic relationships of terrafirme forests in the Brazilian Amazon. For. Ecol. Manage., 146: 169-179.

Poulsen, A.D. 1996. Species richness and density of ground herbs within a plot of lowland rainforest in north-west Borneo. $J$. Trop. Ecol., 12: 177-190.

Poulsen, A.D.; Balslev, H. 1991. Abundance and cover of ground herbs in an Amazonian rain forest. J. Veg. Sci., 2: 315-322.

Ranzani, G. 1980. Identificação e caracterização de alguns solos da Estação Experimental de Silvicultura Tropical. Acta Amazonica, 10: 7-41.

Ribeiro, J.E.L.S.; Hopkins, M.J.G.; Vicentini, A.; Sothers, C.A.; Costa, M.A.S.; Brito, J.M.; Souza, M.A.D.; Martins, L.H.P.; Lohmann, L.G.; Assunção, P.A.C.L.; Pereira, E.C.; Silva, C.F.; Mesquita, M.R.; Procópio, L.C. 1999. Flora da Reserva Ducke: guia de identificação das plantas vasculares de uma floresta de terrafirme na Amazônia Central. INPA/DFID, Manaus, Brasil.

Ribeiro, M.N.G. 1976. Aspectos climatológicos de Manaus. Acta Amazonica, 6(2): 229-233.

Smith, A.P. 1987. Respuestas de hierbas del sotobosque tropical a claros ocasionados por la caída de árboles . Ecología y ecofisiología de plantas en los bosques mesoamericanos. D.A. Clark, R. Dirzo e N.Fetcher (eds) Rev. Biol. Trop., 35, suplemento 1.

Terborgh, J.; Andresen, E. 1998. The composition of Amazonian forests: patterns at local and regional scales.J. Trop. Ecol., 14: 645-664.

Ter Steege, H. 2000. Plant Diversity in Guyana. Wageningen, The Tropenbos Foundation. Tropenbos Series 18.

Tuomisto, H.; Ruokolainen, K 1994. Distribution of Pteridophyta and Melastomataceae along an edaphic gradient in an Amazonian rain forest. J. Veg. Sci., 5: 25-34.

Tuomisto, H.; Poulsen, A.D. 1996. Influence of edaphic specialization on pteridophyte distribution in Neotropical rain forests. J. Biogeog., 23: 283-293.

Turner, I.I.; Tan, H.T.W.; Chua, K.S. 1996. Relationships between herb layer and canopy composition in a tropical rain forest successional mosaic in Singapore.J. Trop. Ecol., 12:843-851.

Whitmore, T.C.; Peralta, R.; Brown, K. 1985. Total species count in a Costa Rican rain forest.J. Trop. Ecol., 1: 375-378.

RECEBIDO EM 02/06/2003 ACEITO EM 03/12/2003 
